\title{
Flash flood evolution in North-Western Mediterranean
}

\author{
Maria Carmen Llasat ${ }^{\mathrm{a}}$, Raül Marcos ${ }^{\mathrm{a}}$, Montserrat Llasat-Botija ${ }^{\mathrm{a}}$, Joan Gilabert ${ }^{\mathrm{a}}$, Marco \\ Turco $^{\mathrm{b}}$, Pere Quintana-Seguí ${ }^{\mathrm{c}}$ \\ ${ }^{a}$ Dept. Astronomy and Meteorology, Faculty of Physics, University of Barcelona, Spain \\ (carmell@am.ub.es) \\ ${ }^{\mathrm{b}}$ ISAC-CNR, Turin, Italy \\ 'Observatori de l’Ebre, URL-CSIC, Roquetes, Spain
}

\begin{abstract}
The present paper shows an in-depth analysis of the evolution of floods and precipitation in Catalonia for the period 1981-2010. In order to have homogeneous information, and having in mind that not gauge data was available for all the events, neither for all the rivers and stream flows, daily press from a specific newspaper has been systematically analysed for this period. Furthermore a comparison with a longer period starting in 1900 has been done. 219 flood events (mainly flash flood events) have been identified for the period of 30 years (375 starting in 1900), 79 of them were ordinary, 117 of them were extraordinary and 23 of them were catastrophic, being autumn and summer the seasons with the maxima values. $19 \%$ of the events caused a total of 110 casualties. $60 \%$ of them died when they tried to cross the street or the stream. Factors like the evolution of precipitation, population density and other socioeconomical aspects have been considered. The trend analysis shows an increase of 1 flood/decade that probably has been mainly due to inter-annual and intra-annual changes in population density and in land-use and land-cover.
\end{abstract}

Key words: floods, flash floods, press data, vulnerability, societal impact, climate change

\section{Introduction}

Floods constitute the main natural hazard in the world (UNISDR, 2009). More than 280 disasters are produced every year by floods or storms (including hurricanes and tornadoes), this is to be compared to an annual average of 31 disasters associated with earthquakes and 6 with volcanoes. Annually, 105,000,000 people are affected by floods, which is much higher than the 41,000,000 who might be affected by storms, tornadoes and hurricanes (UNISDR, 2009). According to "Flood Risks to People" (DEFRA), in the twentieth century $12 \%$ of deaths caused by natural catastrophes were a consequence of floods, and between 1980 and 2000, 170,000 deaths were registered (Dao and Peduzzi, 2004).

The analysis of the distribution of floods in the Mediterranean for the period 1990-2006 (Llasat et al., 2010a), showed a total of 185 episodes of flooding, some of which affected more than one basin, and even more than one country. In total, they caused 4,500 victims and damage exceeding $€ 29,000$ million, with Italy being the country that 
registered the greatest economic losses over that period. In Spain, floods constitute the main natural hazard. As a consequence $62 \%$ of the payments made by the Spanish public reinsurer "Consorcio de Compensación de Seguros"(CCS), between 1971 and 2010, are related to floods. This corresponds to $€ 4,476,230,631$ (actualized at 31/12/2010). The last catastrophic event recorded in Catalonia was produced by the Garonne floods recorded on $13^{\text {th }}$ June in the Pyrenean Region (Val d'Aran) with associated costs to the CCS of near 20 million of euros.

At the European level, the European Directive on Floods (DIRECTIVE 2007/60/CE, European Parliament, 2007) regulates flood risk management plans, focusing on prevention, protection and preparation. It takes into account the fact that many European basins are shared between different countries or regions within countries, thereby bringing into play the solidarity principle. In the first phase of this Directive, "Preliminary Evaluation of Flood Risk", information on past floods is compiled and the most catastrophic episodes are reanalyzed.

In Catalonia (region situated in the NE of the Iberian Peninsula), this function is carried out by INUNCAT, a Civil Protection Plan on the Risk of Floods in Catalonia (DGPC, 2012). In addition to establishing advisories and plans of action in emergency situations, the Plan also provides risk cartography at a municipal scale, based on geomorphological and hydraulic calculations and estimates of river flood return periods of 50, 100, and 500 years. According to INUNCAT, more than $40 \%$ of municipalities in Catalonia have a high or very high flood risk. The coastal fringe, where the majority of the population is concentrated, is the most affected area due to the presence of numerous delta plains and river and stream outlets (Fleta et al., 2006). Following the INUNCAT plan, the Catalan Water Agency (ACA) began its "River Area Planning" (PEFCAT) for the Internal Basins of Catalonia. Currently, and as a consequence of the European Directive on Floods, the ACA, in collaboration with the Civil Protection, is carrying out flood risk management plans which are comprised of three phases: Preliminary Flood Risk Evaluation (APRI), preparation of Flood Risk Danger Maps (MAPRI) and generation of Flood Risk Management Plans (PGRI), anticipated in 2015. Unlike other regions or countries such as France or Italy, these projects have been more focused on modelling than on the recovery and analysis of historical information.

At present there are numerous efforts to create flood databases, despite the difficulties that this implies. Indeed, it is often very difficult, if not impossible, to obtain continuous series of streamflow data. As a consequence, data from insurance companies, newspapers, specific post-event questionnaires, damage refund requests, technical reports or historical archives are used instead. In this sense, problems emerge due to lack of homogeneity, contradictory information, differing criteria, etc. which need to be taken into consideration in order to construct quality data series (Petrucci, 2012; Petrucci and Pasqua, 2008, 2009; Polemio and Petrucci, 2012). However the advantage of this approach is that useful information is obtained for evaluating flood risks since information on flood impacts is also included. This type of database is usually elaborated for specific regions (Llasat et al., 2013a) (PRIM-NET database (MEDDTL, 
2011); AVI (Damaged Urban Areas (Guzzetti et al., 1994)); ASICAL (database of floods and landslides in Calabria (Petrucci and Pasqua, 2008, 2009) and are more complete than the official data referring to catastrophic events such as EM-DAT (Emergency Events Database from the Centre for Research on the Epidemiology of Disasters of the Université Catholique de Louvain (Barredo, 2009)) and NATHAN (Natural Hazards Assessment Network of the reinsurance firm Munich Re), which have the advantage of covering large land areas, but present numerous deficiencies.

One of the applications of such a database is the study of the temporal and spatial evolution of floods. The latest report from the IPCC (2012), "Managing the Risks of Extreme Events and Disasters to Advance Climate Change Adaptation (SREX)", warns of the potential growth of natural risks around the world. In the case of extreme temperatures and heat waves, the impact of global warming as a consequence of climate change is evident; however it is not as clear in other risk areas such as flooding, in which the growing vulnerability and land-use and land-cover changes play a predominant role. The report insists on the rise in economic damages in developed countries, due in part to the rise in insured property and GDP (Barredo, 2009, Barredo et al., 2012), but also due to growing populations in flood-prone areas. As an example, between 1985 and 2006, the population in the countries on the Mediterranean coastline rose from 352 to 450 million people, most of them concentrated on the coast, and in many regions close to torrential watercourses.

Studies analysing trends in historical floods and paleofloods show maximums associated with natural causes such as the beginning and end of the Little Ice Age (Llasat et al., 2005), in periods of high irregularity in rainfall and thawing. The majority of studies detect no significant trend with respect to catastrophic flooding, but a rise in extraordinary floods since the nineteenth century (Barriendos et al, 2003; Llasat et al, 2005; 2013a). Usually, these trends are more related with changes in hydrological conditions and an increased vulnerability (Mouri et al., 2011).The qualifiers "catastrophic" or "extraordinary" refer to impacts of the floods, being the catastrophic those that cause great damages, including the total or partial destruction of buildings or infrastructures, and great losses in agriculture. The extraordinary events are those for which the overflow can destroy temporal infrastructures located in the river, and some damage or partial destruction to hydraulic installations, buildings or infrastructures near the river, (Barriendos et al., 2003; Llasat et al., 2005, 2013a; Barrera et al, 2006).

The objective of the present paper is to perform an in-depth analysis of the evolution of floods and precipitation in Catalonia for the period 1981-2010. This has been achieved with precipitation data from E-OBS (ENSEMBLES daily gridded observational dataset) and a flood database derived from newspaper data and other sources.

\section{Study area and data base}


(a)

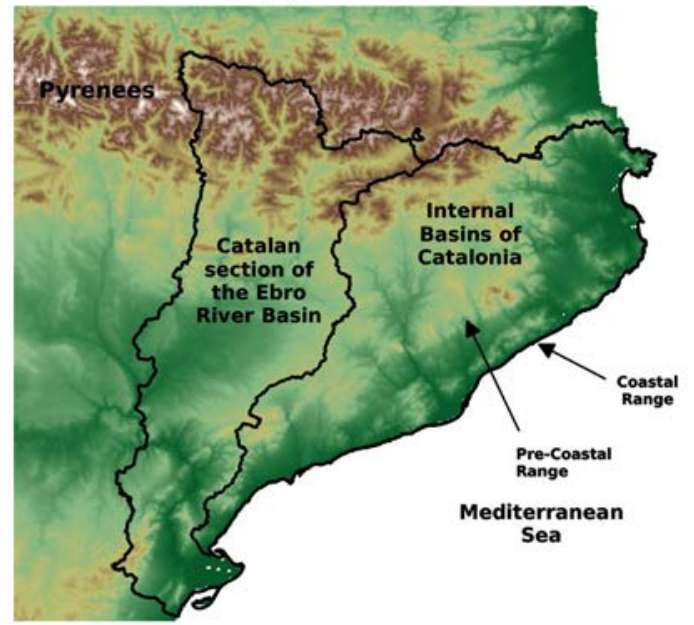

(b)

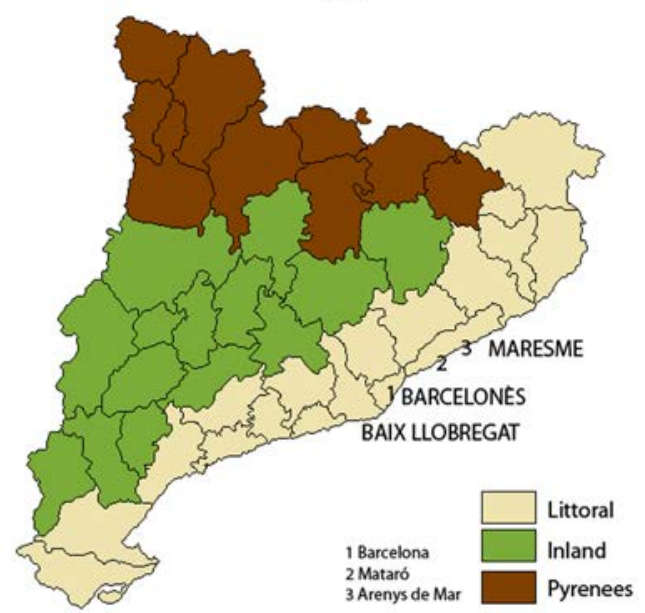

Fig. 1. Map of Catalonia showing the orography and main river basins (a) and the counties (b). The counties and municipalities cited in the text are labelled. The counties have been classified in three areas Littoral, Inland and Pyrenees.

Catalonia is located in the Northeast of the Iberian Peninsula. Its surface area of 31,930 $\mathrm{km}^{2}$ is bounded on the north by the Pyrenees (altitudes above 3,000 m.a.s.l.) and on the East by the Pre-coastal Range (1,700 m.a.s.l) and the Coastal Range (700 m.a.s.l), both situated parallel to the Mediterranean coast. The hydrographical network is made up of the tributary waters of the Ebro basin and the Internal Basins of Catalonia (Fig. 1a). From an administrative point of view, the region is divided in 41 counties and 947 municipalities which, in this study, are grouped into three main regions: the Pyrenees, the coastal region, and the inland region (Fig. 1b), in order to make results comparable to those obtained by Barnolas and Llasat (2007) for the period 1900-2000.

\subsection{Flood and news data}

In order to carry out this study, a database was created containing events that produced floods in Catalonia in the 1981-2010 period, without specifying the degree of severity. The database was constructed in a Geographic Information System (ArcGIS), with an associated MS Access database. This database contains information such as the date, the counties and municipalities affected, the main rivers or basins involved, the impacts produced, and the type of flood: ordinary (0), extraordinary (1), or catastrophic (2). Extraordinary and catastrophic floods have already been defined in the introduction. Ordinary floods are those than can produce flooding of some restricted areas and overflowing depends on the degree of river bed obstruction; they can produce minor damage to hydraulic installations such as mills or irrigation channels, as well as cars parked in the torrential channel with non permanent flow. Since the study is carried out on a regional scale, each flood-producing event is classified according to its highest degree of impact. Furthermore, in some events, rainfall and discharge measurements are available. In the database, the length of the flood event is determined by the beginning and end of rainfall, thus meaning it may last more than one day. The criteria adopted, 
including the selected period, are coherent with the flood database being created by the HYMEX program (HYdrological Mediterranean Experiment, Llasat et al., 2013a).

The construction of this database was inspired by two previous studies. The first of these is the creation of the INUNGAMA database which contained information regarding all of the flood events that affected this region in the 1901-2000 period (Barnolas and Llasat, 2007). In some localities it was extended to the fourteenth century (Llasat et al., 2005; Barrera et al., 2006). The advantage of this database is that it spans a long time period, although the heterogeneity among the data sources is a disadvantage (it must be noted that long series of streamflow data are generally not available). The second study was PRESSGAMA, a database containing all news items related to natural risks, climate change, and sustainable development, exceeding 14,000 news articles from 1982 to 2007 (Llasat et al., 2009).

Both databases were updated for this study after a systematic analysis of all the news items published by "La Vanguardia". This newspaper is one of the longest-running (the first publication was on 1 February, 1881), prestigious, and consolidated newspapers in Spain, which is especially centred on news from Catalonia since it is based in Barcelona. In studies by Llasat et al. (2009), Petrucci and Pasqua (2008) and FitzGerald et al. (2010), it has been pointed out that using the press can have limitations, though it is important to note that it is the most widely referenced resource for reconstructing data series on natural risks. Upon completion for the 1981-2010 period, there are approximately 16,000 news articles on record, $25 \%$ of which make reference to floods. In addition to the press, information from other sources was also acquired (official reports, data from insurance companies, etc.).

In comparison with databases from other countries with information on floods such as EM-DAT and NATHAN, the information available here is more contrasted and extensive. Indeed, EM-DAT and NATHAN contain only a few events classified as catastrophic within their respective criteria (Llasat et al., 2013b), whereas the database used in this article contains all episodes which produced floods with some degree of impact. This is significant, considering that the Mediterranean region frequently undergoes flash floods that are not catastrophic but that produce large accumulative costs.

\subsection{Precipitation data}

The analysis of precipitation trends was carried out using the E-OBS database, the only one that covers the present study period. E-OBS (v.7.0) is a high-resolution daily precipitation, temperature, and pressure dataset covering Europe and the MediterraneanAfrican coast during the period 1950 to June $2013\left(0.25^{\circ}\right.$ x $0.25^{\circ}$, approximately $25 \mathrm{~km} \mathrm{x}$ $25 \mathrm{~km})$. For information about its development and analysis, readers are referred to Haylock et al. (2008). 
Previous rainfall trend studies using SPAIN-02 were taken into account (Herrera et al., 2012), for which there is no information available that covers the entire period.

\subsection{Economic impact and societal data}

Population data was obtained at county and municipality level from the Statistics Institute of Catalonia (IDESCAT). It was compiled through municipal registers and estimates from 1981 to 2012.

Information regarding economic damages was completed through reports from the "Consorcio de Compensación de Seguros" (CCS), a Spanish national reinsurance company that covers losses due to significant risks through economic compensations so long as a contracted insurance policy is held. The CCS has a complete database, though it is not available for public distribution (Barredo et al., 2012). However the annual CCS report contains, among other information, the annual compensations for flood damage as well as specific information for the most relevant events. In the 1971-2010 series, events considered relevant were those that caused flood damages surpassing 20,900,000 Euros in total, updated in December 2010.

\section{Spatial distribution of flood events}

A total of 219 flood events were recorded during the period 1981-2010. The geographic distribution emphasizes the high concentration of these events along the coast, due to the presence of torrential streams, a higher frequency of intense convective and highly localized rainfall events, and greater vulnerability and exposure, since this area has the highest concentration of population, industry, and services. Thus, considering the areas shown in Fig. 1, the coastal region is affected by $71 \%$ of events, compared to $19 \%$ in the interior region and $10 \%$ in the Pyrenees.

Fig. 2 shows the distribution by counties, with a maximum in the Maresme at 105 events (48\% of the total), which is equivalent to three events per year. Other counties that stand out are the Barcelonès with 67 events and the Baix Llobregat with 66. These three counties alone are home to $46 \%$ of the population of Catalonia. The Maresme in particular is traversed by numerous torrential streams around which the settlements of the county are constructed. This county is also a tourism and leisure destination, causing the population to rise by $10 \%$ in summer, increasing the impact posed by flooding (Llasat et al., 2010b). 


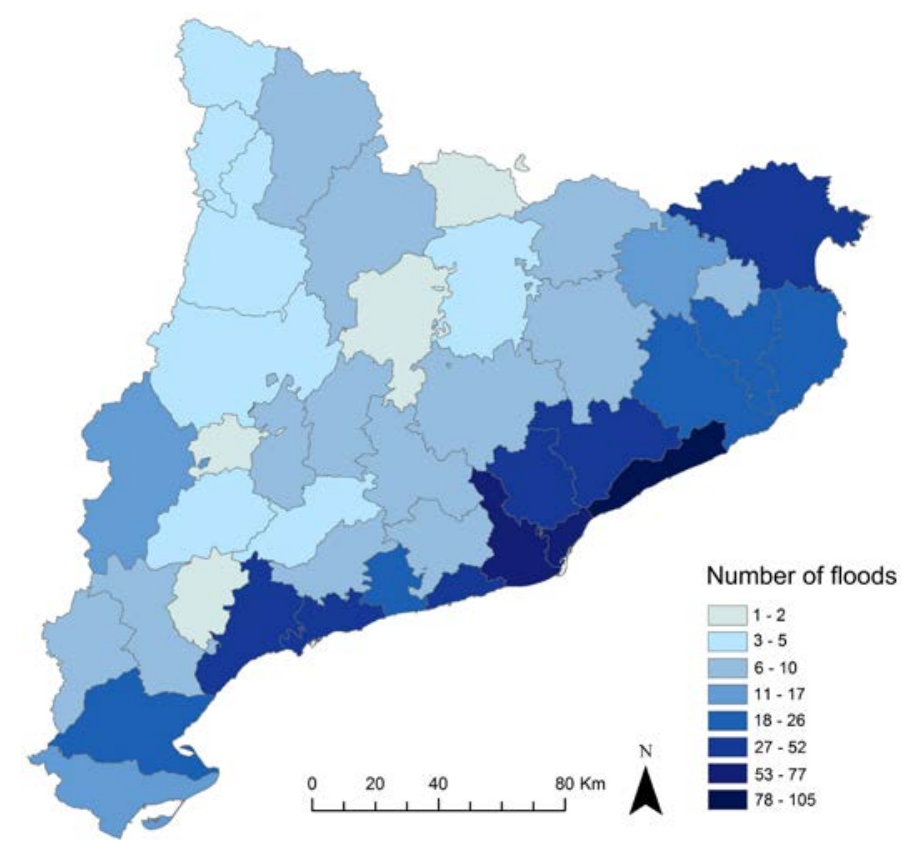

Fig. 2. Distribution of the number of flood events by counties (1981-2010)

The most affected municipalities are those that lie directly on the coast, as observed in Fig. 3. This distribution is due to higher vulnerability and exposure, in addition to the fact that streams bring with them large quantities of solid materials, increasing along their trajectory. Barcelona (Fig. 1b) is the most affected municipality with a total of 64 flood events, although damages in the city are generally not catastrophic, due to its network of pluvial deposits and drainage (Barrera et al., 2006). In the Maresme, the municipalities of Arenys de Mar and Mataró stand out (Fig. 1b) with 47 and 37 events, respectively. It is important to note that Barcelona is the third most densely populated municipality in Catalonia with 15,978 inhabitants $/ \mathrm{km}^{2}$ while Arenys de Mar and Mataró have densities of 2,295 and 5,455 inhabitants $/ \mathrm{km}^{2}$, respectively (IDESCAT, 2010). 49\% of municipalities in Catalonia have been affected by flooding and 44 municipalities, that is, nearly $5 \%$ of the total, have undergone more than 10 flood events. In fact, all municipalities along the coast with populations over 20,000 inhabitants have exceeded 10 events. 


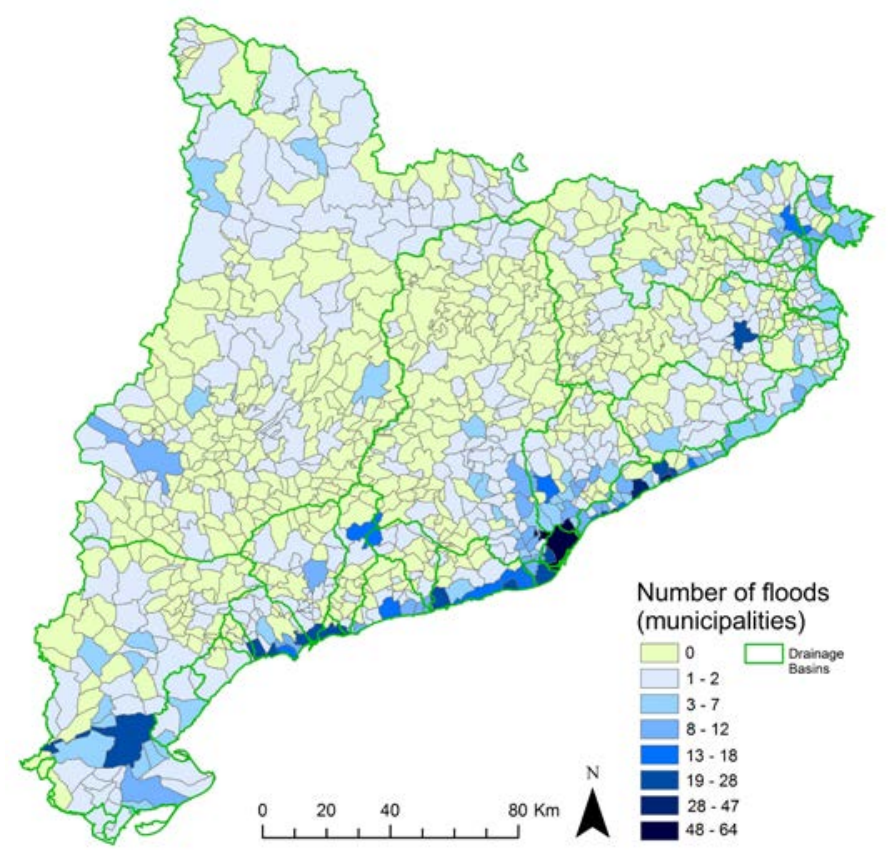

Fig. 3. Distribution of flood events by municipalities (1981-2010)

Of the 219 flood events registered between 1981 and 2010, 36\% are classified as ordinary, $53 \%$ as extraordinary, and $11 \%$ as catastrophic (Fig. 4). The Maresme was affected by $61 \%$ of extraordinary events which provoked flash floods generated by very local and intense rainfall, which, in some cases, exceeded $3 \mathrm{~mm} / \mathrm{min}$ or $50 \mathrm{~mm}$ in less than an hour (Llasat, 2009). These are very local episodes associated with convective precipitation (Llasat, 2001). Conversely, in the Barcelonès, this type of episode tends to cause minor damages and traffic disruptions (40\% of episodes affecting the county produced only ordinary floods), and the situation is improved by the existing measures of flood prevention. It is also important to note that the majority of catastrophic events that affected this county occurred in the first decades of the study period, especially the floods of October 1987 and 1996, which brought about the proposal and construction of pluvial deposits in order to manage flooding. However the Baix Llobregat, where $41 \%$ of floods were catastrophic, includes the airport, the main transport nodes, and numerous residential areas built in flood-prone areas. 

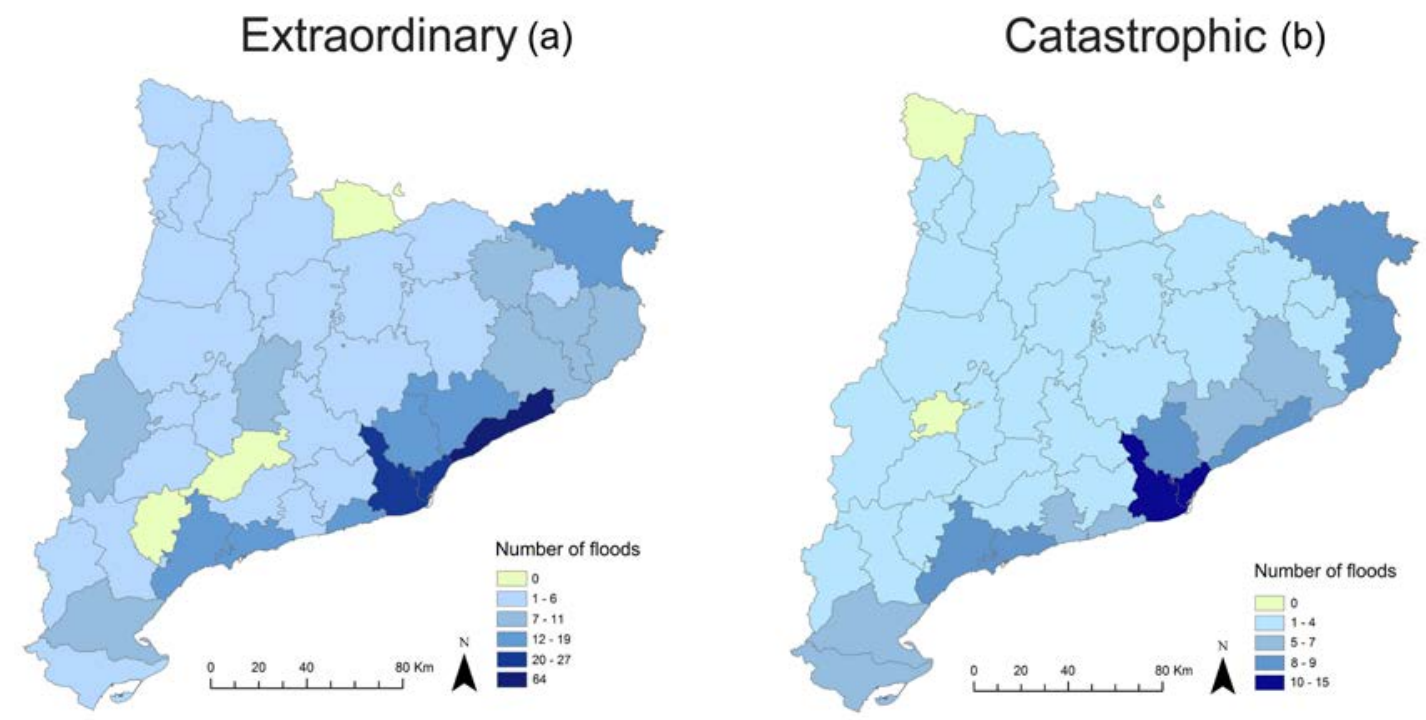

Fig. 4. Distribution by counties affected by extraordinary flood events (a) and catastrophic flood events (b) (1981-2010)

The exhaustive compilation of information carried out in this study for the years 1981 to 2010, as mentioned in the chapter on databases, has increased the number of registered flood events for the 1981-2000 period from the 75 identified by Barnolas and Llasat (2007) to 136.

\section{Annual distribution of flood events}

The majority of flood events occur between August and November. 48\% occur in autumn (SON) and 33\% in summer (JJA), especially in September with $23 \%$ and August with $16 \%$. The prominence of September and August is due to events that affect the coastal region, with a 24\% flood occurring in September and 18\% in August (Fig. 5). These are generally events of extraordinary nature produced by flash floods (Fig.6). In fact, September is the month with the highest number of floods in all regions, insofar that in August very few floods are recorded in the interior counties and the Pyrenees. October and November are the months with the highest number of catastrophic events (26\% and $30 \%$, respectively) and, as a consequence, $75 \%$ of this type of events is recorded in autumn (Table 1). These events are of greater duration and extent than in summer, they are very convective or moderately convective, affect large drainage basins and can produce rainfall exceeding $500 \mathrm{~mm}$ in 24 hours. Some examples would be the events recorded in 6-8 November 1982, with a total above $600 \mathrm{~mm}$ in less than $72 \mathrm{~h}$ in the Eastern part of Pyrenees (Llasat, 2009) or 2-5 October 1987 that overpassed 400 mm near Barcelona (Ramis et al, 1994). The conceptual synoptic model associated to this kind of autumn flood events (Llasat, 2009) shows a previous long anticyclonic situation over the Mediterranean which favours the formation of a Mediterranean air mass and a strong potential instability; the presence of any Mediterranean low, a convergence line or a mountain barrier organizes the differentiated air currents as well 
as internal low frontal boundaries and usually forces the ascent of the warm-wet current and the release of the convective instability; the presence of the European anticyclone favours the Southeastern circulation over Catalonia, and the stationarity of the process. A through or a cut off low in high levels favours the advection of potential vorticity (Martin et al, 2007) and the flow organization.

\begin{tabular}{|l|l|l|l|l|}
\hline & Ord. & Ext. & Cat. & Total \\
\hline Winter & 8 & 10 & 2 & 20 \\
\hline Spring & 10 & 11 & 0 & 21 \\
\hline Summer & 29 & 41 & 4 & 73 \\
\hline Autumn & 33 & 55 & 18 & 105 \\
\hline
\end{tabular}

Table 1. Number of flood events for each season and category.

The results differ from those obtained for the 1900-2000 period by Barnolas and Llasat (2007), in which the maximum frequency occurred in October (24\%), followed by September (20\%), and August (15\%). This difference is more a consequence of differing degrees of homogeneity in the data than of climatic causes since the 19002000 database (INUNGAMA) probably overestimated the frequency of catastrophic floods compared to the total number of events, and these occurred primarily in October and November, as indicated above. This change must be taken into consideration when studying the impact of climate change on flooding in this region since, until now, more attention was given to autumn while summer was hardly considered.

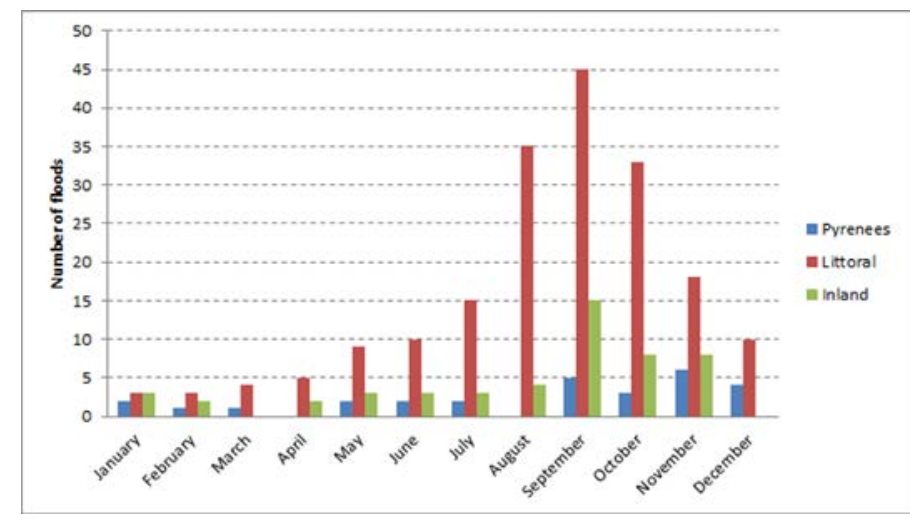

Fig. 5. Monthly distribution of flood events by regions (1981-2010). 


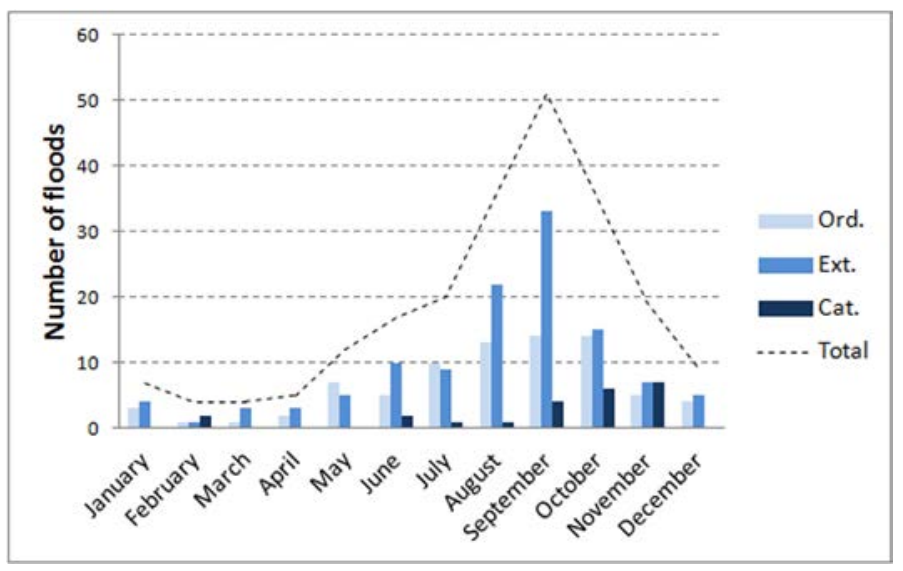

Fig. 6. Monthly distribution of flood events by categories and total (1981-2010).

\section{Year-to-year distribution of flood events}

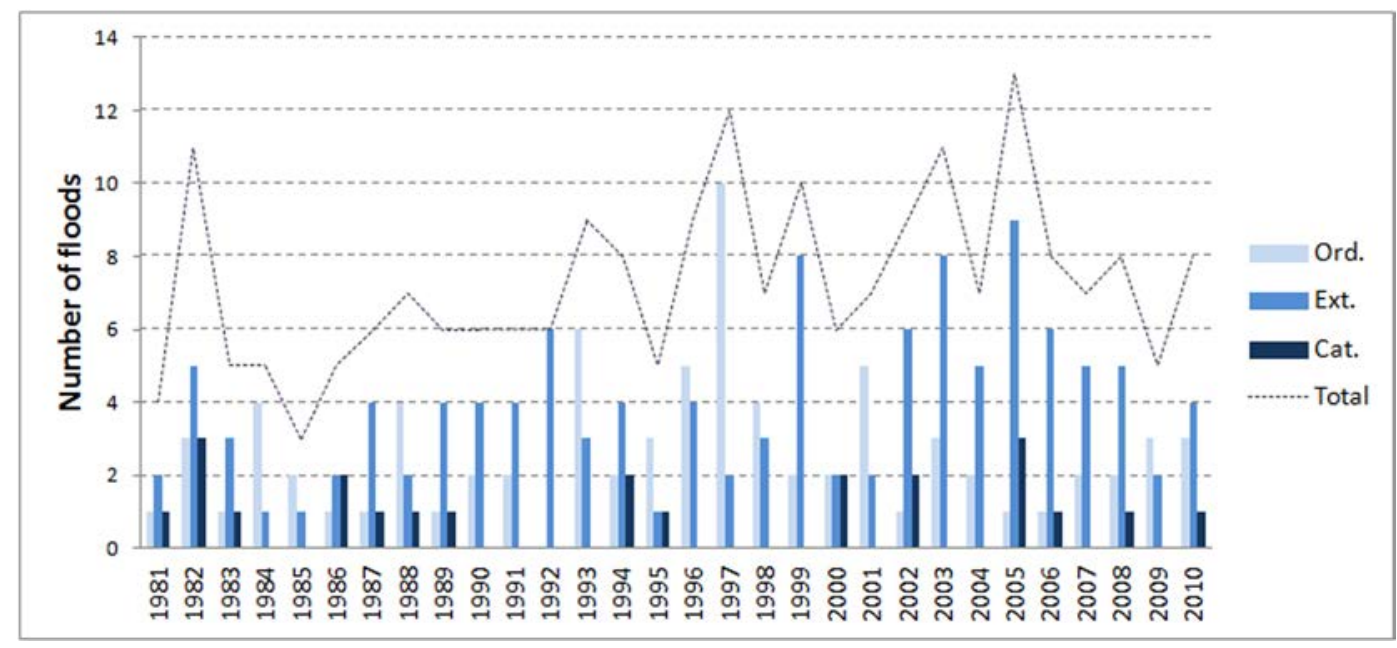

Fig. 7. Temporal evolution of flood events by categories and total (1981-2010)

Analyses of the year-to-year evolution of flood events indicate a positive trend. The trend significance is estimated with the Monte-Carlo test implemented by Turco and Llasat (2011). This method consists in: (i) decomposing the data series into a linear trend line and a time series of residuals, (ii) resampling the residuals 1000 times and adding them back to the best fit line obtaining 1000 new plausible trend estimations, (iii) estimating the original trend significance considering if the zero-trend falls outside the distribution of these 1000 plausible trend values. We also compare the results to those obtained using a Mann-Kendall method (Mann 1945; Kendall 1975).

After applying both methods, the results indicate that the trend in the total number of flood events is significant at $95 \%$ with an increment of 1.0 floods/ decade. This trend is much stronger than that determined by Barnolas and Llasat (2007), with 0.2 events/ decade (significant at 95\%), which at the time was thought to be the result of increased information in recent decades. The positive trend obtained here for a homogeneous period of 30 years confirms its robustness. By categories, the ordinary and catastrophic events do not show significant trends while the extraordinary events exhibit behaviour 
similar to the total number of floods, with a trend of 1.0 events/ decade, significant to $95 \%$.

In the analysis by seasons, only summer (JJA) shows a trend with a significance level of 95\% according to the Mann-Kendall test, but because it is not confirmed by the MonteCarlo method, its representativeness is limited. Regarding regional trends, only the coastal region shows a trend with a significance level of 95\% with an evolution of 1.1 floods/ decade for both tests. Fig. 8 shows the regional distribution of these floods during the 1981-2010 period.

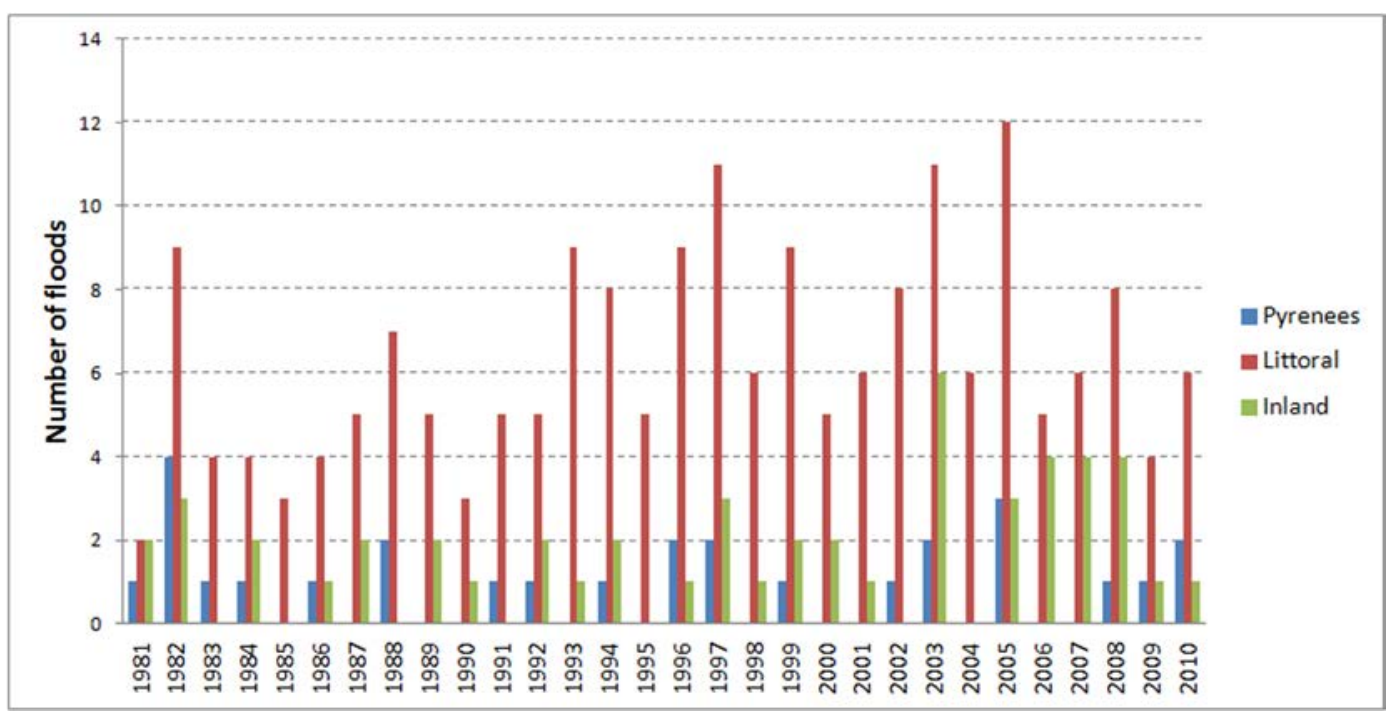

Fig. 8. Temporal evolution of flood events by regions (1981-2010).

Comparing the 1900-1980 period with the 1981-2010 period, it should be noted that the Pyrenees and the interior regions (where the rivers have tributaries from the Pyrenees) have a relative maximum in April in the first period, but not in the second. This variation may be related to temperature increases (Turco et al. 2012) and other climate changes that contribute to reduce the floods that usually occurred in early spring when snow thaw becomes a contributing factor, as emphasized by various authors (i.e. Revuelto, et al., 2012).

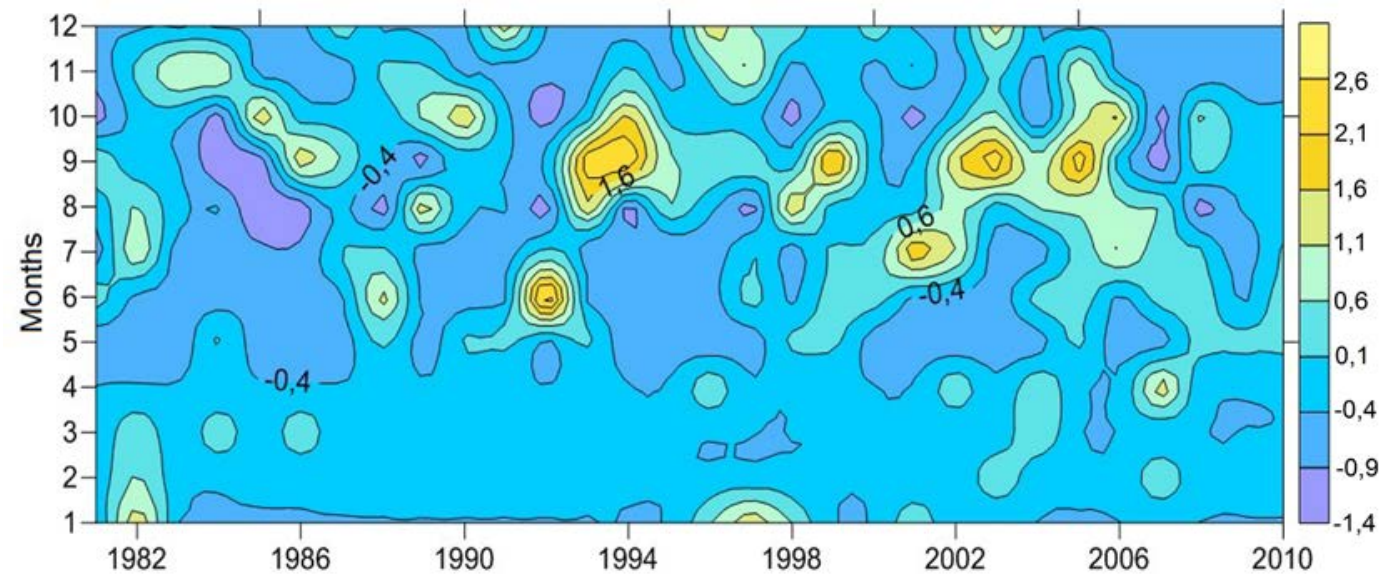


Fig. 9. Temporal evolution of the relative frequency distribution of the normalized monthly flood events (1981-2010).

Fig. 9 assists in analysing seasonal variation. This dual axis graph represents normalized flood characteristics, allowing the positive and negative anomalies to be observed according to both criteria (year/month). The isolines were interpolated using the Kriging method. The normalization was carried out using the same methodology as in other studies on the evolution of precipitation in this area (Rodríguez et al., 1999; Llasat and Quintas, 2004) so that they would be comparable. The following expression was applied:

$\mathrm{z}(\mathrm{t}, \mathrm{m})=(\mathrm{x}(\mathrm{t}, \mathrm{m})-\mathrm{x}(\mathrm{m})) / \sigma(\mathrm{m})$

Where: $\mathrm{z}(\mathrm{t}, \mathrm{m})$ is the normalized value, $\mathrm{x}(\mathrm{t}, \mathrm{m})$ is the number of events in month $\mathrm{m}$ and year $t, x(m)$ is the average number of events per month and $\sigma(m)$ is the monthly standard deviation.

The positive anomalies are concentrated mostly in the months of August, September, and October, and specifically from 1993 to 2006. The rest of the graph is composed mostly of negative results that tend towards zero, resulting in little variability.

\section{Evolution of precipitation trends}

An analysis of yearly and monthly precipitation trends based on E-OBS data for the 1981-2010 period shows no significant trend for the whole of Catalonia, confirming the results obtained by other authors for various periods (i.e. Saladié et al., 2004, 2006, 2007; González-Hidalgo et al., 2009). However for November in the coastal and precoastal areas there is a decrease in precipitation of between 10 and $30 \mathrm{~mm} /$ decade, significant at 95\% with both methods (Fig. 10). Some studies, such as Altava-Ortiz et al. (2010) and Paredes et al. (2006) indicated a significant decrease in spring, but no author detected a rise in precipitation in the months with most frequent flooding in this region.

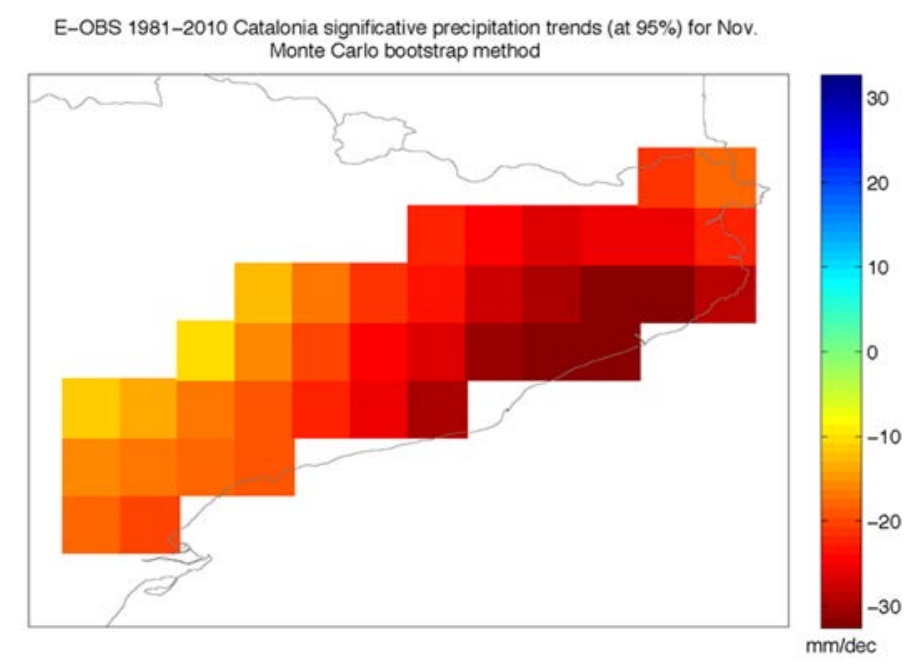


Fig. 10. Significant precipitation trend for November, obtained from the E-OBS database (1981-2010).

The evolution of the ETCCDI (Expert Team on Climate Change Detection and Indices) indexes for intense rainfall such as PRCPTOT (total precipitation on wet days, $\mathrm{P}>1$ $\mathrm{mm}$ ), RX1DAY and RX5DAY (Highest precipitation amount in one (five)-day period), and SDII (Simple Daily Intensity Index, it is to say, mean precipitation amount on a wet day), showed no significant and sufficiently common representative trends. It is important to note that a similar result was previously observed for longer periods in certain locations in Catalonia (Turco and Llasat, 2011) and Portugal (Santos and Fragoso, 2013). In fact, from the relevant bibliography, the only significant trend is that of SDII (Llasat and Corominas, 2010; SMC, 2012) for the period 1973-2003 (although it is not robust) in which there is notable dipolar behaviour in summer, with a negative trend in a large part of the Pyrenees and the Interior region, with a positive trend on the central coast including the counties Maresme, Baix Llobregat, and Barcelonès. In this sense, Mosmann et al (2004) also found a statistically positive and significant trend in wide areas of the South of Spain, related with a potential increase of convective precipitation.

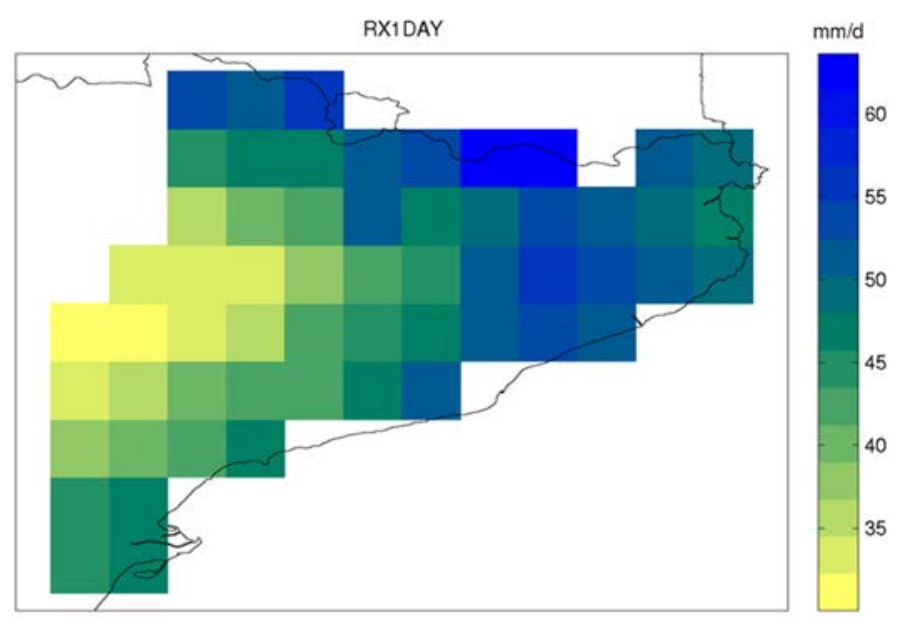

Fig. 11. Spatial distribution of the index RX1DAY: Highest precipitation amount in one-day period (mm/d) (1981-2010).

The RX1DAY index, that could be considered a proxy for torrential rainfall (Fig. 11) shows a greater concentration of high values on part of the coast and in the Pyrenees. This distribution is in agreement with the study of the distribution of convective precipitation in the Internal Basins of Catalonia (Llasat et al., 2007), according to which, in the Maresme and the Barcelonès, 30\% of annual precipitation is convective in nature with an annual contribution exceeding $150 \mathrm{~mm} /$ year.

\section{Impacts of flooding}

Of the 219 flood events, 42 caused a total of 110 fatalities. 69\% of catastrophic floods produced victims, though the percentage is much lower with extraordinary floods at 14\% (Table 2). Concerning the number of events that caused deaths, there are two 
peaks, one in the year 1982 (with 5 events) and another in the year 2005 (with 4 events). $60 \%$ of events that caused fatalities occurred in autumn, where September is the month with the most events (26\%), followed by August and November (both with 19\%) and October with 14\%. Specifically, the events that caused the most victims were those of 6 November 1982 (14), 28 September 1987 (10), 8 November 1988 (9), and 9 October1994 (10), which amount to $39 \%$ of the total number of victims.

Referring directly to the number of victims, 64\% of fatalities were a consequence of catastrophic events, followed by $24 \%$ associated with extraordinary floods. Thus there is a relation of 0.2 victims per extraordinary event while in the case of catastrophic events, this index rises to 3.0. In this type of events, $90 \%$ of fatalities occurred in autumn. Concerning the total number of fatalities, $76 \%$ occurred in autumn, where November was the month with the highest number (29\% of all victims), followed by September (26\%), October (20\%), and August (9\%) (Fig. 12). It is important to note that these percentages are highly influenced by the four major events mentioned above. With regard to the temporal evolution during the 1981-2010 period, no significant trend is observed, neither in the number of events causing fatalities, nor in the number of victims. This result supports the conclusions of Barnolas and Llasat (2007) for the 1900-2000 period.

The causes of death are known for $80 \%$ of fatalities: $70 \%$ were caused by being swept away while crossing a flooded street or stream on foot or in a vehicle. These are cases, therefore, which could be prevented through improving risk awareness among the local population. Of the $45 \%$ of cases in which the gender of the victims was known, $73 \%$ were males. Finally, it is important to note that at least eight flood victims were foreign citizens (either on holiday or resident immigrants) who were likely unaware of the violent nature of the flash floods that tend to occur in Catalonia.

\begin{tabular}{|l|l|l|l|l|l|}
\hline Category & $N_{e}$ & $N_{e-\text { casualties }}$ & $N_{\text {casualties }}$ & $N_{\text {casualties }} N_{e}$ & $\begin{array}{l}N_{\text {casualties dragged by }} \\
\text { water }\end{array}$ \\
\hline Ordinary & 79 & 9 & 14 & 0,18 & 5 \\
\hline Extraordinary & 117 & 17 & 26 & 0,22 & 22 \\
\hline Catastrophic & 23 & 16 & 70 & 3,04 & 35 \\
\hline TOTAL & 219 & 42 & 110 & 0,50 & 62 \\
\hline
\end{tabular}

Table 2. Distribution of flood events $\left(N_{e}\right)$; events that caused casualties $\left(N_{e-\text { casualties }}\right)$, number of total casualties by categories ( $\left.N_{\text {casualties }}\right)$, number of casualties by event and number of casualties caused by water dragging (into a car or outside). 


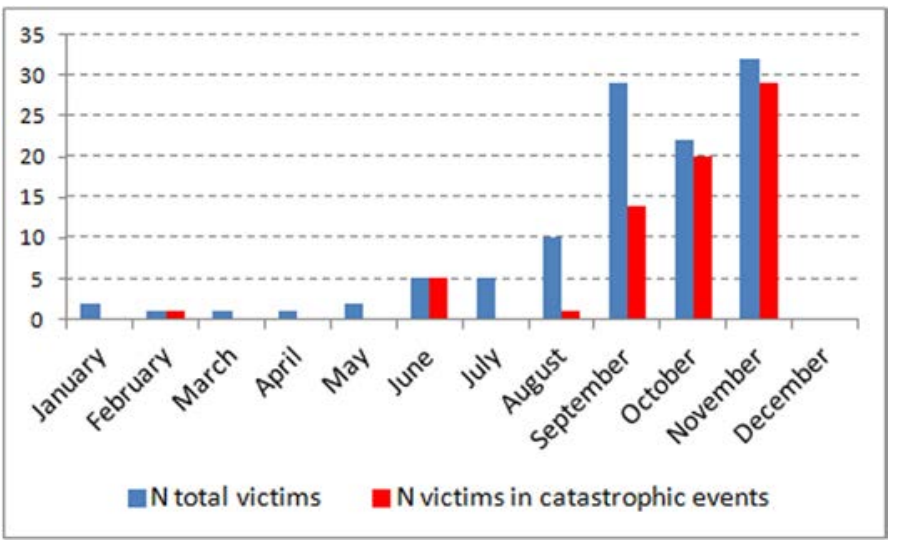

Fig. 12. Monthly distribution of the number of casualties (1981-2010)

Regarding the number of municipalities affected by each of the 23 catastrophic flood events, no significant trend is observed. There is also a lack of trends in the results of the Damaged Area Index, which is defined as the ratio between the total area of the municipalities affected by each event and the total surface area of Catalonia, expressed in percentage (Fig. 13). As is common in such cases, this data series is highly influenced by the most serious catastrophic events in November 1982, SeptemberOctober 1987, and October 1994. This type of indicators, as utilized in Fig. 14 to estimate socio-economic impacts, is common in the bibliography on this topic (i.e. Messner and Meyer, 2006; Petrucci and Pasqua, 2009). Thus, of the 14 indicators shown in Fig. 14, all can be considered to have caused damages to roads, streets, and buildings, downing telephone and electricity lines, and causing crop losses, alterations in public services and, most notably, vehicles lost or displaced by high flood currents.

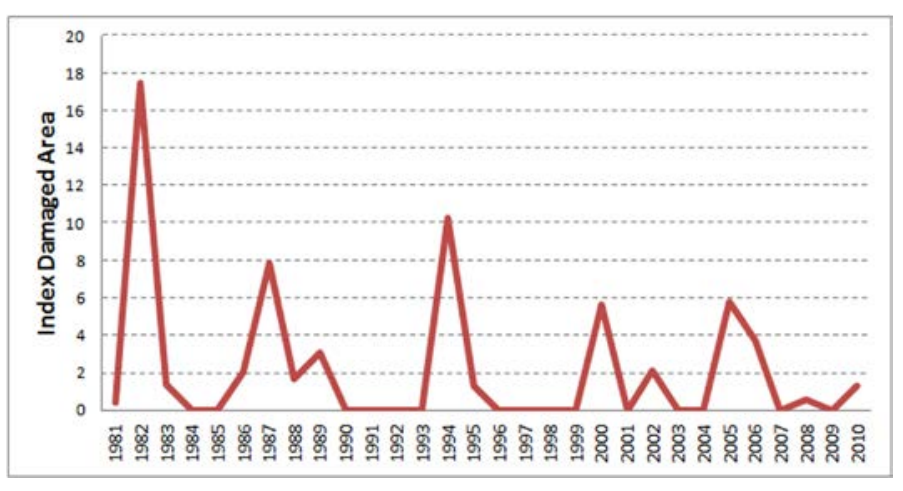

Fig. 13. Evolution of the Index Damaged area in catastrophic flood events (1981-2010). 


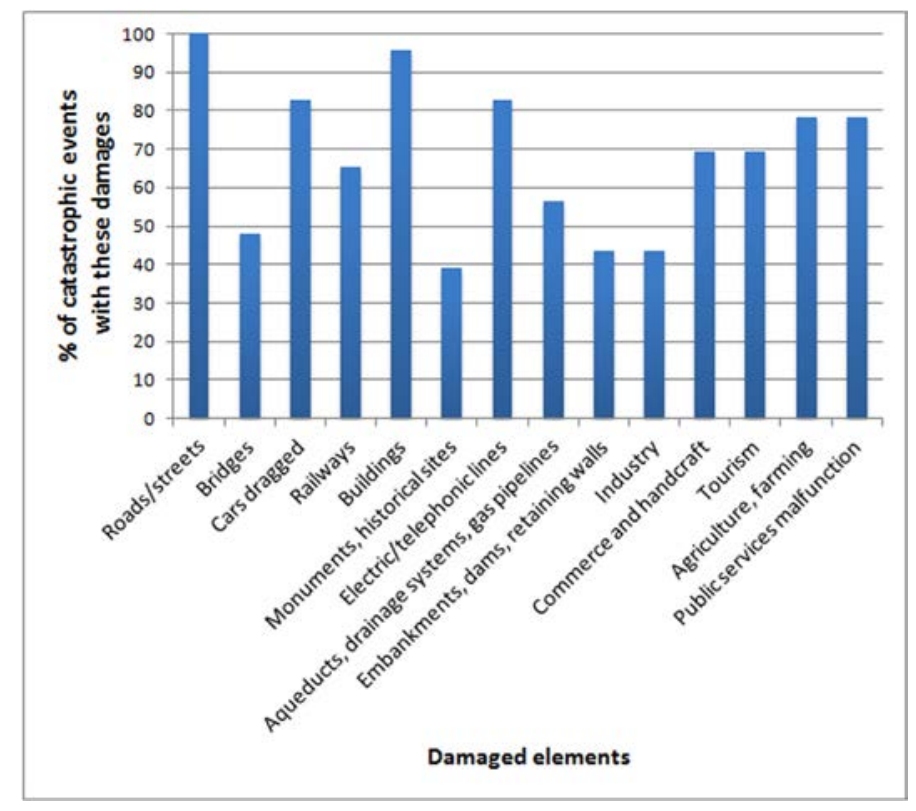

Fig. 14. Percentage of different catastrophic flood damages (1981-2010)

Table 3 shows the 10 most economically damaging events affecting Catalonia, according to the compensations paid by the reinsurance company Consorcio de Compensación de Seguros (CCS, 2011), updated on 31 December 2010 to enable data comparison. The CCS defines the term "Great Event" as those that exceeded $€ 20,900,000$ in compensations. Of the 10 events included in this list, 9 occurred in autumn. The event that occurred in October 1994 caused the greatest economic damage, and although it was not the event with the largest extent or the highest precipitation, it affected the Port of Tarragona and the neighbouring industrial area. The most extensive event registered occurred in November 1982 (the second in economic rank), and also severely affected Aragon, as well as Andorra and France, destroying entire settlements. The compensations paid for the event in October 2005 also include damages caused by tornados. Of the 10 events, 8 were catastrophic. The remaining 2 were classified as extraordinary, occurring on 2 September 1996 and 13-14 September 1999, the first of which caused massive damages in Valencia (more than $€ 20,000,000$ paid in compensations) and the Balearic Islands. The 1999 event covered a wide extent but was not destructive, though the consequences of flooding on 13 and 14 September were likely grouped with the compensations for four other extraordinary events in that month.

In comparison, in the entire Spanish State, 62\% of all compensations paid between 1971 and 2010 were for flood damages, according to the CCS. Examining the monthly distribution for the period comprising 1987 to 2010 in further detail shows that $20 \%$ of sums paid were for events that occurred in September, $18 \%$ for events in November, and $18 \%$ for events in October (5\% in August).

\begin{tabular}{|l|l|l|l|l|}
\hline Date & $N \quad$ municipalities & $N$ & Compensations paid (in & $P_{\text {TOTAL }}$ MAX \\
\hline
\end{tabular}




\begin{tabular}{|l|l|l|l|l|}
\hline (dd/mm/yyyy) & affected & casualties & Euros (2010) & $(\mathrm{mm})$ \\
\hline $6-8 / 11 / 1982$ & 99 & 14 & $56,765,055$ & 556 \\
\hline $6-7 / 11 / 1983$ & 14 & 3 & $26,053,695$ & 347 \\
\hline $28 / 9-5 / 10 / 1987$ & 78 & 10 & $30,798,386$ & 431 \\
\hline $9-11 / 10 / 1994$ & 63 & 10 & $74,496,789$ & 397 \\
\hline $21 / 9 / 1995$ & 19 & 1 & $30,804,763$ & 253 \\
\hline $2 / 9 / 1996$ & 15 & 1 & $8,405,138$ & 100 \\
\hline $13-14 / 9 / 1999$ & 25 & 1 & $47,313,431$ & 95 \\
\hline $10 / 6 / 2000$ & 26 & 5 & $36,593,988$ & 224 \\
\hline $11-14 / 10 / 2005$ & 33 & 4 & $49,546,653$ & 350 \\
\hline $12-14 / 9 / 2006$ & 37 & 1 & $63,038,554$ & 267 \\
\hline
\end{tabular}

Table 3. Great events in Catalonia between 1971 and 2010 according to CCS. An event is considered like a great event when the compensations paid are higher than 20,900,000 Euros of 2010. The flash-flood event of 1996 is included because it also affected the Valencia region and Balearic Islands with a total compensation of 29,737,737 euros.

No significant trend is observed regarding the possible increase in compensations paid as a consequence of catastrophic events. This result, although hardly relevant due to the small sample size, should be analysed with the same perspective as in the article by Barredo et al. (2012) regarding the analysis of trends in insured losses from floods in Spain, 1971-2008. Indeed, in this study there is an increasing trend in the original losses explained by socio-economic factors such as increases in exposure of insured properties, the value of exposed assets, and insurance penetration. However, this trend is not observed when considering adjusted insured flood losses.

In order to gain an initial idea about a possible relationship between precipitation and economic damages, the potential relationship between them was analysed, specifically the ten catastrophic events for which reliable information from the CCS (2010) was available. The results indicate that there is no significant correlation between compensations paid and maximum precipitation, which is largely due to the fact that in very extensive events, the number of claims is very high. As a result, a normalized index was used in the study, since it provides a ratio between paid compensations and the number of claims. In this case, there is a significant correlation with maximum precipitation with $\mathrm{r}=0.69$.

\section{Conclusions}


All studies currently indicate that the increase in natural risks worldwide is due to increased vulnerability and economic impact and perception, rather than increased hazardousness. More specifically, the European Directive (DIRECTIVE 2007/60/CE, European Parliament, 2007) and the IPCC (2012), noted that an increase in human settlements and economic goods on alluvial plains, a reduction of the natural water retention capacity of soil as a consequence of land use changes (including deforestation and impermeabilisation), along with climate change, are contributing to an increasing potential for floods worldwide, as well as increasingly negative impacts.

Thus, it is important to approach the study of floods from a global perspective that also takes into account improved techniques for prevention, prediction, emergency management, and recovery. This also depends on the inherent characteristics of the flood. It is possible to distinguish between different types, ranging from flash floods (occurring as a consequence of highly convective, short-duration, local, and intense rainfall), to floods over large basins (associated with long-duration, essentially stratiform rainfall, with embedded convection in some areas). An understanding of the essential physical characteristics of such events, as well as their spatial and temporal distribution in certain areas, would be of great help in improving prevention.

With this aim, all flood events that affected Catalonia between 1981 and 2010 were analysed. Of the 219 events identified, 71\% affected coastal municipalities, in particular the counties Maresme with 105, Barcelonès with 67, and Baix Llobregat with 66. The majority of these events are classified as "extraordinary", that is, without complete infrastructure or housing destruction or great agricultural losses. These are generally events associated with very short, convective rainfall episodes that produce flash floods in areas with high population density or with important industrial hubs or transportation routes and that occur mainly between August and September. Furthermore, in the Maresme the population increases $10 \%$ in summer as a consequence of tourism and summer holiday-makers.

Analysing the temporal evolution in extraordinary events reveals an increase of 1 event per decade, not explainable by increased associated precipitation. Regardless, causes must be investigated in other factors, such as land-use and land-cover changes, which would provoke changes in runoff, and especially the growing occupation of flood zones during the study period.

Catastrophic floods, which can all be linked to maximum rainfall exceeding $200 \mathrm{~mm}$, comprise $10.5 \%$ of the total of events and occur mainly between September and November. In this case, no significant trend in frequency is observed.

Considering the impacts of flooding, 42 deaths were caused as a consequence of the 219 events recorded, of which $69 \%$ were catastrophic and 14\% were extraordinary. The majority of victims, predominantly male, were the result of imprudent behaviour and could have been avoided with heightened risk awareness among the population, as well as better information for non-permanent residents. In addition to victims, a large number of events caused ruptures in transportation routes and electrical and telephone 
services, as well as alterations in public services and vehicles being swept away by floodwaters. In catastrophic events, there are further outcomes such as the destruction of infrastructure and housing, agriculture, and industries, as well as indirect impacts. The temporal analysis, however, does not indicate a growing trend in the number of victims or compensations paid by the CCS, not even for major events after being adjusted with respect to the year 2010. Even so, it is possible that there is an increase in damages produced by extraordinary floods. This is one of the objectives of future studies which could not be undertaken here due to a lack of reliable and obtainable information.

Lastly, in the case of precipitation, a certain correlation (0.69) is observed between the average sums paid as compensation for major events and the maximum rainfall for the same event. This type of correlation ought to be analysed for all events once this information becomes available. Similarly, in this study precipitation indexes with a maximum resolution of 1 day were used. Since the majority of incidences are caused by flash floods, one remaining challenge is to study sub-daily data.

In future work we will deepen the meteorological analysis of each of catastrophic events, considering its thermodynamic and dynamic features. This kind of analysis will be useful to characterize them, to find common features and to compare with previous works on the matter, and to analyse the potential impact of climate change in the different meteorological patterns that could produce a change in seasonality or frequency.

\section{Acknowledgements}

This work was performed within the European project DRIHM (Distributed Research Infrastructure for Hydro-Meteorology. Project n. 283568 UE Framework Programme 7) and the program HyMeX (Hydrological Mediterranean Experiment). It was also partially supported by the Italian project of Interest "NextData" of the Italian Ministry for Education, University and Research. We acknowledge the E-OBS dataset from the EU-FP6 project ENSEMBLES (http://ensembles-eu.metoffice.com) and the data providers in the ECA\&D project (http://www.ecad.eu). Our thanks to La Vanguardia and Consorcio de Compensación de Seguros (CCS). We thank Dani Mast for the translation of this article.

\section{References}

Agència Catalana de l'Aigua (ACA), 2013. Avaluació preliminar del risc d’inundació en el districte de conca fluvial de Catalunya.

Altava-Ortiz, V., Llasat, M.C., Ferrari, E., Atencia, A., Sirangelo, B., 2010. Monthly rainfall changes in Central and Western Mediterranean basins, at the end of the 20th and beginning of the 21st centuries, Int. J. Climatol. 31, 1943-1958. 
Barnolas, M., Llasat, M.C., 2007. A flood geodatabase and its climatological applications: the case of Catalonia for the last century. Nat. Hazards Earth Syst. Sci. 7, 271-281.

Barredo, J.I., 2009. Normalised flood losses in Europe: 1970-2006. Nat. Hazards Earth Syst. Sci. 9, 97-104.

Barredo, J. I., Saurí, D., Llasat, M. C., 2012. Assessing trends in insured losses from floods in Spain 1971-2008. Nat. Hazards Earth Syst. Sci. 12, 1723-1729.

Barrera, A., Llasat, M.C., Barriendos, M., 2006. Estimation of extreme flash flood evolution in Barcelona County from 1351 to 2005. Nat. Hazards Earth Syst. Sci. 6, 505518.

Barriendos, M., Coeur, D., Lang, M., Llasat, M. C., Naulet, R., Lemaitre, F., Barrera, A., 2003. Stationarity analysis of historical flood series in France and Spain (14th-20th centuries). Nat. Hazards Earth Syst. Sci. 3, 583-592.

Consorcio de Compensación de Seguros (CCS), 2011, Estadística. Riesgos extraordinarios. Serie 1971-2010.

Dao, H., Peduzzi, P., 2004. Global evaluation of human risk and vulnerability to natural hazards. Enviro. Info. 1, 435-446.

Direcció General de Protecció Civil de Catalunya (DGPC), 2012. Pla Especial d'emergències per inundacions (INUNCAT).

FitzGerald G, Du W, Jamal A, Clark M, Hou X., 2010. Flood fatalities in contemporary Australia (1997-2008). Emerg Med Australas 22:180-186

Fleta, J., Godé, L., Gomá, J. L., Gracia, À., Gracia, J., Martínez, J., Verdaguer, I. 2006. Flooding areas and risk analysis of Catalonia (Inuncat Plan), in: Artiol G.P., Pignone, R., Montanarella, L., Berástegui, X., Roca, A.M., Lagally, U., Schmid, H., Christmann, P. (Eds.), 5th European Congress on Regional Geoscience Cartographyand Information Systems. Institut Cartogràfic de Catalunya, Barcelona, pp. 458-460.

Gonzalez-Hidalgo, J.C.; López-Bustins, J.A.; Stepánek, P., Martin-Vide, J., De Luís, M., 2009. Monthly precipitation trends on the Mediterranean fringe of the Iberian Peninsula during thesecond-half of the twentieth century (1951-2000). Int. J. Climatol. 29, 1415-1429.

Guzzetti, F., Cardinali, M., and Reichenbach, P., 1994. The AVI Project: A bibliographical and archive inventory of landslides and floods in Italy, Environ. Manage. 18, 623-633.

Haylock, M. R., Hofstra, N., Klein Tank, A. M. G., Klok, E. J., Jones, P. D., New, M., 2008. A European daily high-resolution gridded data set of surface temperature and precipitation for 1950-2006. J. Geophys. Res. 113, 1-12. 
Herrera, S., Gutiérrez, J.M., Ancell, R., Pons, M.R., Frías, M.D., Fernández, J., 2012. Development and analysis of a 50-year high-resolution daily gridded precipitation dataset over Spain (Spain02). Int. J. Climatol. 32, 74-85.

Institut d'Estadística de Catalunya (IDESCAT, Statistical Institute of Catalonia), 2010. Anuari estadístic de Catalunya (Statistical Yearbook of Catalonia), http://www.idescat.cat/.

IPCC, 2012: Managing the Risks of Extreme Events and Disasters to Advance Climate Change Adaptation. A Special Report of Working Groups I and II of the Intergovernmental Panel on Climate Change [Field, C.B., V. Barros, T.F. Stocker, D. Qin, D.J. Dokken, K.L. Ebi, M.D. Mastrandrea, K.J. Mach, G.-K. Plattner, S.K. Allen, M. Tignor, and P.M. Midgley (eds.)]. Cambridge University Press, Cambridge, UK, and New York, NY, USA, 582 pp.

Kendall, M. G., 1975. Rank Correlation Measures. Charles Griffin, London.

Llasat, M.C., 2001. An objective classification of rainfall events on the basis of their convective features: application to rainfall intensity in the northeast of Spain. Int. J. Climatol. 21, 1385-1400.

Llasat, M.C., 2009. Storms and Floods, in: Woodward, J.C. (ed.), The Physical Geography of the Mediterranean. Oxford University Press, Oxford, pp. 513-540.

Llasat, M.C., Quintas, L., 2004. Stationarity of monthly rainfall series, since the middle of the XIXth century. Application to the case of peninsular Spain. Nat. Hazards Earth Syst. 31, 613-622.

Llasat, M. C., Barriendos, M., Barrera, A., Rigo, T., 2005. Floods in Catalonia (NE Spain) since the 14th century. Climatological and meteorological aspects from historical documentary sources and old instrumental records. J. Hydrol. 313, 32-47.

Llasat, M.C., Ceperuelo, M., Rigo, T., 2007. Rainfall regionalization on the basis of the precipitation convective features using a raingauge network and weather radar observations. Atmos. Res. 83, 415-426.

Llasat, M.C., Corominas, J., 2010. Riscos associates al clima, in: Llebot, J.E. (Ed), Segon informe sobre el canvi climàtic a Catalunya. Institut d'Estudis Catalans i Generalitat de Catalunya, Departament de la Vicepresidència, Consell Assessor per al Desenvolupament Sostenible de Catalunya, pp. 243-307

Llasat, M.C., Llasat-Botija, M., López, L., 2009. A press database on natural risks and its application in the study of floods in Northeastern Spain. Nat. Hazards Earth Syst. Sci. 9, 2049-2061.

Llasat, M. C., Llasat-Botija, M., Prat, M. A., Porcú, F., Price, C., Mugnai, A., Lagouvardos, K., Kotroni, V., Katsanos, D., Michaelides, S., Yair, S., Savvidou, K., 
Nicolaides, K., 2010a. High impact floods and flash floods in Mediterranean countries: the flash preliminary database. Adv. Geosci., 23, 1-9.

Llasat, M. C., Llasat-Botija, M., Rodríguez, A., Lindbergh, S., 2010b. Flash floods in Catalonia: a recurrent situation. Adv. Geosci. 26, 105-111.

Llasat, M.C., Llasat-Botija, M., Petrucci, O., Pasqua, A., Rosselló, J., Vinet, F., Boissier, L., 2013a. Towards a database on societal impact of Mediterranean floods within the framework of the HYMEX project. Nat. Hazards Earth Syst. Sci. 13, 13371350 .

Llasat, M.C., Llasat-Botija, M., Petrucci, O., Pasqua, A., Rosselló, J., Vinet, F., Boissier, L., 2013b. Floods in the north-western Mediterranean region: presentation of the HYMEX database and comparison with pre-existing global databases. Houille Blanche. 1, 5-9.

Mann, H. B., 1945. Nonparametric tests against trend. Econometrica. 13, 245-259.

Martín, A., Romero, R., Homar, V., de Luque, A., Alonso, S., Rigo, T., Llasat, M.C., 2007: Sensitivities of a flash flood event over Catalonia: a numerical analysis. Mon. Weather Rev., 135, 651-669.

MEDDTL (French Ministry of Environment): Tableau des événements naturels dommageables survenus en France de 1900 à 2010, available at: http://catalogue.prim.net/94), 2011.

Messner, F., Meyer, V., 2006. Flood damage, vulnerability and risk perception Challenges for flood damage research, in: Schanze, J., Zeman, E., and Marsalek, J., Flood Risk Management: Hazards, Vulnerability and Mitigation Measures. Springer, Berlin, pp. 149-167.

Mouri, G., Kanae, S., Oki, T., 2011. Long-term changes in flood event patterns due to changes in hydrological distribution parameters in a rural-urban catchment, Shikoku. Japan. Atmos. Res. 10, 164-177.

Mosmann, V., Castro, A., Fraile R., Dessens J., Sanchez, J.L., 2004. Detection of statistically significant trends in the summer precipitation of mainland Spain. Atmos. Res., 70, 43-53.

Paredes, D., Trigo, R.M., García-Herrera, R., Trigo, I.F., 2006. Understanding precipitation changes in Iberia in early spring: weather typing and storm-tracking approaches. J. Hydrometeorol. 7, 101-113.

Petrucci, O., 2012. Assessment of the impact caused by natural disasters: simplified procedures and open problems, in: Tiefenbacher, J. P. (Ed), Managing Disasters assessing hazards, emergencies and disaster impacts. INTECH, Rijeka, pp. 109-132.

Petrucci, O., Pasqua, A.A., 2008. The study of past damaging hydrogeological events for damage susceptibility zonation. Nat. Hazards Earth Syst. Sci. 8, 881-892. 
Petrucci, O., Pasqua, A. A., 2009. A methodological approach to characterise Landslide Periods based on historical series of rainfall and landslide damage. Nat. Hazards Earth Syst. Sci. 9, 1655-1670.

Polemio, M., Petrucci, O., 2012. The occurrence of floods and the role of climate variations from 1880 in Calabria (Southern Italy). Nat. Hazards Earth Syst. Sci. 12, 129142.

Ramis, C., Llasat, M.C., Genovés, A., Jansà, A., 1994. The october-1987 floods in Catalonia. synoptic and mesoscale mechanisms. Meteorol. Appl. 1, 337-350.

Revuelto, J., López-Moreno, J.I., Morán, E., Fassnacht, S., Vicent, S.M., 2012. Variabilidad interanual del manto de nieve en el Pirineo: tendencias observadas y su relación con índices de teleconexión durante el periodo 1985-2011, in: Rodríguez, C., Ceballos A., González N., Morán, E., Pacheco S., Hernández A. (Eds.). Asociación Española de Climatología, Madrid, pp. 613- 621.

Rodríguez, R., Llasat, M.C., Wheeler, D., 1999. Analysis of the Barcelona precipitation series 1850-1991. Int. J. Climatol. 19, 787-801.

Saladié, O., Brunet, M., Aguilar, E., Sigró, J., López, D., 2004. Variaciones estacionales de la precipitación en el sistema Mediterráneo Catalán, in: Codrón, J.C., Liaño, D., Fernández de Arróyade, P., Garmendia, C., Rasilla, D. (eds), El clima entre el mar y la montaña. Asociación Española de Climatología, Madrid, pp. 399-408.

Saladié, O., Brunet, M., Aguilar, E., Sigró, J., López, D., 2006. Análisis de la tendencia de la precipitación de primavera en la cuenca del Pirineo Oriental durante el periodo 1896-2003, in: Cuadrat, J.M., Saz, M.A., Vicente, S.M., Lanjeri, S., De Luis M., González-Hidalgo, J.C. (Eds.), Clima, Sociedad y Medio Ambiente, Asociación Española de Climatología, Madrid, pp. 475- 486.

Saladié, O., Brunet, M., Aguilar, E., Sigró, J., López, D., 2007. Observar la lluvia en Cataluña: 150 años de registros, first ed. Publicacions URV, Tarragona.

Santos, M., Fragoso, M., 2013. Precipitation variability in Northern Portugal: Data homogeneity assessment and trends in extreme precipitation indices. Atmos. Res. 131, 34-45.

Servei Meteorológic de Catalunya (SMC), 2012. Butlletí anual d’indicadors climàtics. (http://bit.ly/196Zl4j)

Turco, M., Llasat, M.C., 2011. Trends in indices of daily precipitation extremes in Catalonia (NE Spain), 1951-2003. Nat. Hazards Earth Syst. Sci. 11, 3213-3226.

Turco, M., Marcos, R., Quintana-Seguí, P., Llasat, M.C., 2012. Testing instrumental and downscaled reanalysis time series for temperature trends in NE of Spain in the last century. Reg. Environ. Change. 1-13. 
UNISDR, 2009: Unisdr (2009) - UNISDR Terminology on Disaster Risk Reduction [http://www.unisdr.org/eng/terminology/terminology-2009-eng.html 